\title{
Taxonomy of Pimelodus brevis Marini, Nichols \& La Monte, 1933 (Siluriformes: Pimelodidae), an uncertain species from the rio Paraná basin
}

\author{
Marcelo Salles Rocha ${ }^{1}$ and Carla Simone Pavanelli1,2
}

Pimelodus brevis Marini, Nichols \& La Monte, 1933 was described from the río de la Plata, Departamento San Fernando, Argentina, based only on the holotype, which is missing since 1960s. This species has been cited in the literature and is considered valid despite of no voucher specimen has been found in museum. A taxonomic analysis comprising material from the rio Paraná basin provided additional specimens that made it possible to demonstrate the identity of $P$. brevis. Based on the original description and illustration of the holotype, we performed an allometric analysis and then we were able to compare the data with the similar sympatric congeners. Those comparisons allowed us to conclude that $P$. brevis is a junior synonym of $P$. argenteus Perugia, 1891, described from the río Paraná, Colonia Resistencia, Argentina. Comments on the status of congeners and taxonomic recommendations are provided.

Pimelodus brevis Marini, Nichols \& La Monte, 1933 foi descrita do rio de la Plata, San Fernando, Argentina, com base apenas no holótipo, que está desaparecido desde a década de 1960. Esta espécie é considerada válida, a despeito da ausência de espécimes-testemunhos em coleções. Uma análise compreendendo material da bacia do rio Paraná forneceu espécimes adicionais, possibilitando reconhecer a identidade taxonômica de $P$. brevis. Com base na descrição original e na ilustração do holótipo, foi realizada uma análise alométrica e comparação dos dados com as congêneres simpátricas similares. Essas comparações permitiram concluir que $P$. brevis é sinônimo júnior de $P$. argenteus Perugia, 1891, descrita do rio Paraná, Colonia Resistencia (atual Departamento San Fernando), Argentina. Comentários sobre o status de congêneres e recomendações taxonômicas são fornecidas.

Key words: Neotropical, Catfish, Systematics, Pimelodus argenteus, Junior synonym.

\section{Introduction}

The pimelodid genus Pimelodus Lacepède is the most diverse within the family, comprising 33 valid species with a wide geographic distribution through the Neotropical region (Eschmeyer, 2014). The genus is still lacks support by unambiguous synapomorphies, thus many authors have diagnosed it based on characters primarily presented by Eigenmann \& Eigenmann (1890). The taxonomic status of some species have presented problems which include its type species Pimelodus maculatus Lacepède, 1803, poorly described and without type specimen, besides unclear taxonomic status of some species, e.g., P. brevis Marini, Nichols \& La Monte, 1933, poorly described and lacking types.

Pimelodus brevis was described from the río de la Plata, Departamento San Fernando, Argentina and the holotype (AMNH 12240) is missing since 1960s (Lundberg \& Littmann, 2003; Azpelicueta, pers. comm.). Nevertheless some authors have considered it as valid (e.g., Ringuelet, 1940; Pozzi, 1945; Ringuelet et al., 1967; Lundberg \& Littmann, 2003; Ferraris Jr., 2007; Ribeiro \& Lucena, 2007; Ribeiro et al., 2011), in some cases, solely based on the original description and its single illustration of the holotype. A taxonomic analysis comprising material from the rio Paraná basin provided additional specimens that made it possible to demonstrate the identity of Pimelodus brevis.

\section{Material and Methods}

In order to compare Pimelodus brevis to species of Pimelodus from the río de la Plata basin, measurements corresponding to those in the original description were used. These are straight-line distances taken point-to-point with digital calipers on the left side of the fish whenever possible, recorded to the nearest $0.1 \mathrm{~mm}$, and followed Lundberg \& McDade (1986), with the modifications of Lundberg \& Parisi (2002) and Rocha \& Ribeiro (2010). For comparing ratios

${ }^{1}$ Universidade Estadual de Maringá, Programa de Pós-Graduação em Ecologia de Ambientes Aquáticos Continentais (PEA). Av. Colombo, 5790, 87020-900 Maringá, PR, Brazil. marcelo.inpa@gmail.com (corresponding author)

${ }^{2}$ Universidade Estadual de Maringá, Núcleo de Pesquisas em Limnologia, Ictiologia e Aquicultura (Nupélia). Av. Colombo, 5790, 87020900 Maringá, PR, Brazil. carlasp@nupelia.uem.br 
of original descriptions and percentages, the values were converted using the formula $\mathrm{p}=100 / \mathrm{x}$, where $\mathrm{p}=$ ratio and $\mathrm{x}=$ percentage (Graça \& Pavanelli, 2007) and are presented as percentages of standard (SL) or head lengths (HL).

Examined specimens are deposited at the American Museum of Natural History, New York (AMNH); Academy of Natural Sciences of Drexel University, Philadelphia (ANSP); Field Museum of Natural History, Chicago (FMNH); Instituto Nacional de Pesquisas da Amazônia, Manaus (INPA); Museu de Ciências e Tecnologia, Pontifícia Universidade Católica do Rio Grande do Sul, Porto Alegre (MCP); Museo de La Plata, La Plata (MLP); Museu Paraense Emílio Goeldi, Belém (MPEG); Museo Civico di Storia Naturale "Giacomo Doria", Genova, Italy (MSNG); Museu de Zoologia da Universidade Estadual de Londrina, Londrina (MZUEL); Museu de Zoologia da Universidade de São Paulo, São Paulo (MZUSP); Naturhistorisches Museum Wien, Wien (NMW); Coleção Ictiológica do Núcleo de Pesquisas em Limnologia, Ictiologia e Aquicultura, Universidade Estadual de Maringá, Maringá (NUP); Rijksmuseum van Natuurlijke Historie, Leiden (RMNH); and Departamento de Zoologia, Universidade Federal do Rio Grande do Sul, Porto Alegre (UFRGS).

\section{Results}

Pimelodus brevis was described based on a single specimen from the río de la Plata, San Fernando, Argentina, collected by Dr. Tomás Marini in 1932 (Fig. 1). The specimen apparently was cataloged at the Museo Nacional in Buenos Aires, Argentina, under the number 1054a and then was hand carried to The American Museum of Natural History (USA) by Dr. Tomás Marini (Marini, 1934), who, together with J. Nichols and F. La Monte, described the new species of Pimelodus and cataloged the holotype - AMNH 12240 -, which is missing since 1960s (Lundberg \& Littmann, 2003; M. Azpelicueta, pers. comm.).

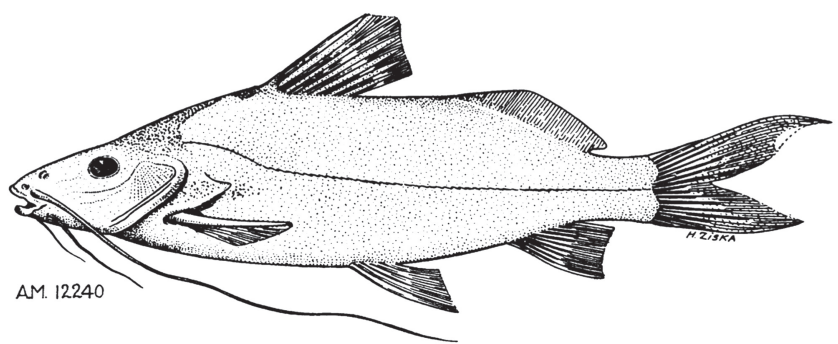

Fig. 1. Pimelodus brevis Marini, Nichols \& La Monte, 1933, holotype, AMNH 12240, $285.0 \mathrm{~mm}$ SL. Modified from Marini et al. (1933).

After the description of P. brevis in 1933, Ringuelet (1940) provided the second citation for the species from the Rosario (Argentina), middle río Paraná. It is supposed that Ringuelet (1940) has examined a specimen named P. brevis, however Ringuelet (1940) provided neither voucher number nor the length of the fish. In the subsequent works some authors have included this location, Rosario, in the geographical range of the species, such as Pozzi (1945), who included P. brevis in a list of freshwater fishes from the Argentina, referring to río Paraná (Rosario) and río de la Plata (San Fernando) as its geographic distribution. Ringuelet \& Arámburu (1957) and Ringuelet et al. (1967) reproduced such information.

Despite the absence of types, some data provided by the authors in the original description help with the identification of $P$. brevis: its color pattern without dark dots; its great standard length $(285 \mathrm{~mm})$; orbital diameter (6.4 times in head, 2 in snout); and body depth $(28.6 \% \mathrm{SL})$. Marini et al. (1933) reported the color pattern of P. brevis: "Specimen in its present condition is without markings, somewhat paler below than above and with fins dark gray. A slightly pale area is indicated along the upper sides differentiating a broad dark lateral shade most obvious posteriorly." Only three species of Pimelodus from the rio Paraná basin have no dark dots on body: P. albicans (Valenciennes, 1840), type locality Buenos Aires, Argentina; P. argenteus Perugia, 1891, type locality río de la Plata, río Paraná, Colonia Resistencia (now Departamento San Fernando), Argentina; and P. atrobrunneus Vidal \& Lucena, 1999, type locality, rio Ligeiro, a tributary to the rio Uruguai, Brazil, endemic from the upper rio Uruguai basin. Pimelodus albicans has some faint dark stripes along the side of the body.

Pimelodus brevis was described based on a single specimen of $285 \mathrm{~mm} \mathrm{SL}$. It is a large specimen since most Pimelodus specimens are less than $300 \mathrm{~mm}$ SL (MSR, pers. obs.). Pimelodus albicans is the largest species reaching up to $485 \mathrm{~mm}$ SL (holotype) (Fig. 2). No specimen of $P$. argenteus larger than $250 \mathrm{~mm}$ (total length) has been found in any museum, and $P$. atrobrunneus is a small species reaching about $200 \mathrm{~mm} \mathrm{SL}$, which also has a shallower body depth (15.9-23.4\% of SL vs. $28.6 \%$ in P. brevis). Marini et al. (1933) gave the following note on P. brevis: "This is an unusually short-bodied species for the genus. In some respects it suggests Pimelodus labrosus [= Iheringichthys labrosus], with which it has been compared." However, it is odd that they have compared a large specimen of P. brevis (280 mm SL) with I. labrosus, that rarely exceeds $200 \mathrm{~mm}$ SL, has a short body depth, a distinct fully ventral mouth and a spotted body, instead of comparing it with other species so common in the rio Paraná basin, such as $P$. maculatus, $P$. argenteus, or P. albicans.

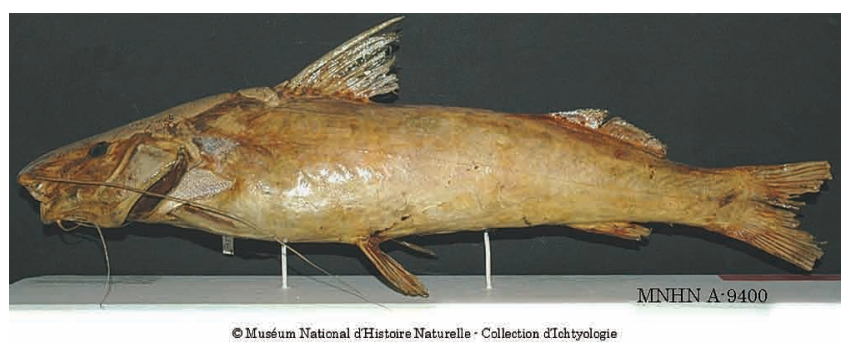

Fig. 2. Arius albicans Valenciennes, 1840 (= Pimelodus albicans), holotype, MNHN 9400, 485 mm SL, BuénosAyres [= Buenos Aires, Argentina]. Photo by Hautecoeur M. 
Some measurements provided by Marini et al. (1933) are listed below and are useful for comparisons. Using the SL and the data given in the paper we calculated some important measurements of P. brevis. However, we did not find any specimen with that size to compare, so the morphometric analyzes may be influenced by allometry. We thus performed a morphometric analysis including the holotype of $P$. brevis (Fig. 1) (based on the description) and specimens of $P$. albicans (73.8-181.3 mm SL) (Fig. 2) and P. argenteus (137.0-204.7 mm SL) (Fig. 3). The presence of small specimens in the analysis showed a strong negative allometry of the orbital diameter related to size (SL) (Fig. 4). The orbital diameter of the holotype of $P$. brevis is contained 6.4 times in HL, whereas $P$. argenteus has larger eye (3.7-4.4 times) and $P$. albicans a very smaller eye (5.3-7.7 times in HL).

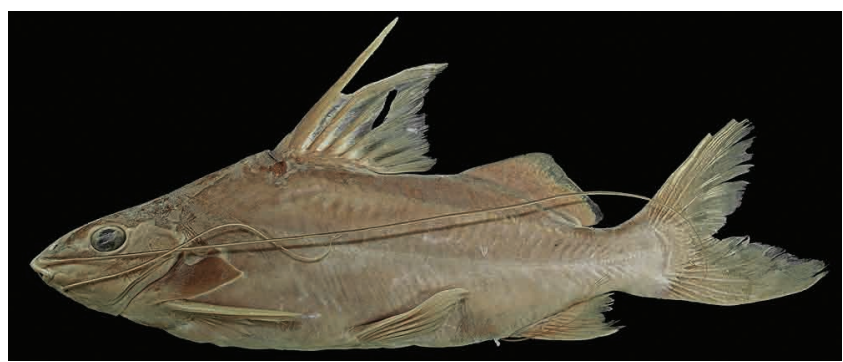

Fig. 3. Pimelodus argenteus, MCP 19248, $204.7 \mathrm{~mm} \mathrm{SL}$, Bella Vista, río Paraná, Corrientes, Argentina. Photo by André Canto.

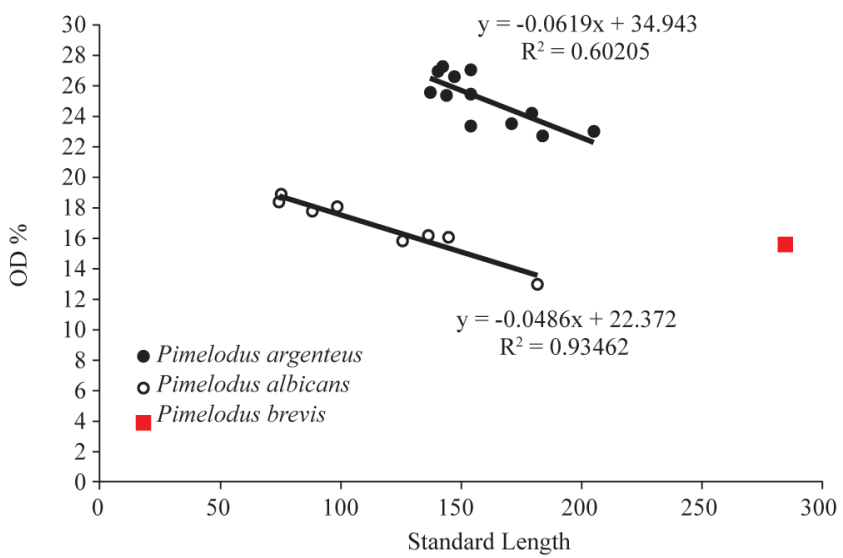

Fig. 4. Linear regression of percent of orbital diameter (OD) on standard length of Pimelodus argenteus, P. albicans, and P. brevis. $\mathrm{R}^{2}=$ coefficient of determination.

Based on those data and on our sample, P. brevis would fit the description of $P$. albicans due to the small size of the orbit (15.6\% of HL vs. $13.0-18.9 \%)$. However, the difference of the standard length of both species is very high, since the largest $P$. albicans analyzed here is $181.3 \mathrm{~mm}$ SL. Based on the Fig. 4, which show the allometry, we may conclude that specimens of $P$. albicans larger than $181.3 \mathrm{~mm}$ SL would have an even smaller orbit diameter. The holotype of $P$. albicans in the MNHN has about $485 \mathrm{~mm} \mathrm{SL}$ and its orbit diameter is 12.2 times in head length (8.2\%) (Fig. 2).
On the other hand, examined specimens of $P$. argenteus (the largest with $204.7 \mathrm{~mm} \mathrm{SL}$ ) (Fig. 3) showed larger eye (22.7-27.3\% of HL) than P. brevis (15.6\% of HL). The Fig. 4 shows that $P$. argenteus and $P$. albicans have negative allometry for that character, and also that the orbital diameters of these two species do not develop at the same rate relative to size or body length. Using the linear equation to estimate the orbit diameter for $P$. argenteus and P. albicans we have $\mathrm{y}=17.3$ and $\mathrm{y}=8.5$, respectively. This result means that a specimen of $P$. argenteus and $P$. albicans with $285 \mathrm{~mm} \mathrm{SL}$ would have an orbital diameter of $17.3 \%$ and $8.5 \%$ of HL, respectively. The estimated orbital diameter for $P$. argenteus $(17.3 \%$ of HL) is almost the same of the holotype of $P$. brevis (15.6\% of HL) for the same SL $(285 \mathrm{~mm})$, whereas for $P$. albicans the eye becomes much smaller ( $8.5 \%$ of HL). This result for $P$. albicans is corroborated by the holotype, which has about $485 \mathrm{~mm} \mathrm{SL}$, with an orbital diameter of $8.2 \%$ of HL.

As stated by Marini et al. (1933), P. brevis is an unusually short-bodied species. We could calculate its body depth as $28.6 \%$ of SL (vs. $20.5-21.3 \%$ of SL in P. albicans and 23.4-29.6 in P. argenteus). As noted in the Fig. 5, the body depth of these species clearly has its proportions altered with the growth, and then the body depth becomes higher in $P$. argenteus whereas in larger specimens of $P$. albicans that percent is shorter. The body depth of the holotype of $P$. albicans is $20.8 \%$ of SL, however based on its current preservation we may have caution in using some measurements related to body. On the other hand, as the head is very ossified and bones bound the orbital diameter, we assume that those measurements related to head are safer.

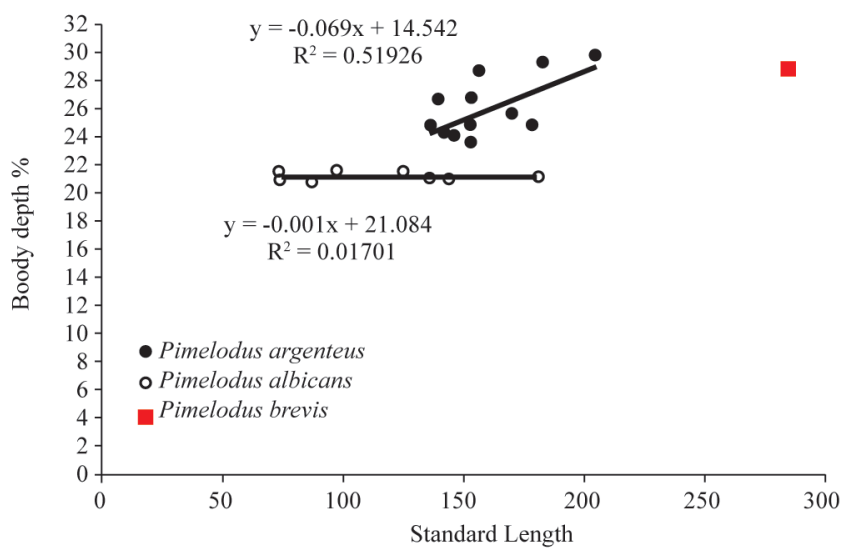

Fig. 5. Linear regression of percent of body depth on standard length of Pimelodus argenteus, P. albicans, and P. brevis. $\mathrm{R}^{2}$ $=$ coefficient of determination.

The interorbital and supraoccipital processes of $P$. brevis are strongly convex, as stated by Marini et al. (1933). We can see a tightly convex interorbital and supraoccipital processes in $P$. argenteus (Fig. 3), whereas $P$. albicans has a flat head, notably in larger specimens (Fig. 2). Another feature provided by those authors is related to the adipose 
fin. As $P$. brevis is a short-bodied species, the adipose fin is close to the dorsal fin and this can be observed in specimens of $P$. argenteus (Fig. 3) whereas in P. albicans the adipose fin is more distant from the dorsal fin.
Based on the original description with illustration provided by the authors, and the data given here we conclude that Pimelodus brevis Marini, Nichols \& La Monte, 1933 is a junior synonym of $P$. argenteus Perugia, 1891 (Fig. 6).

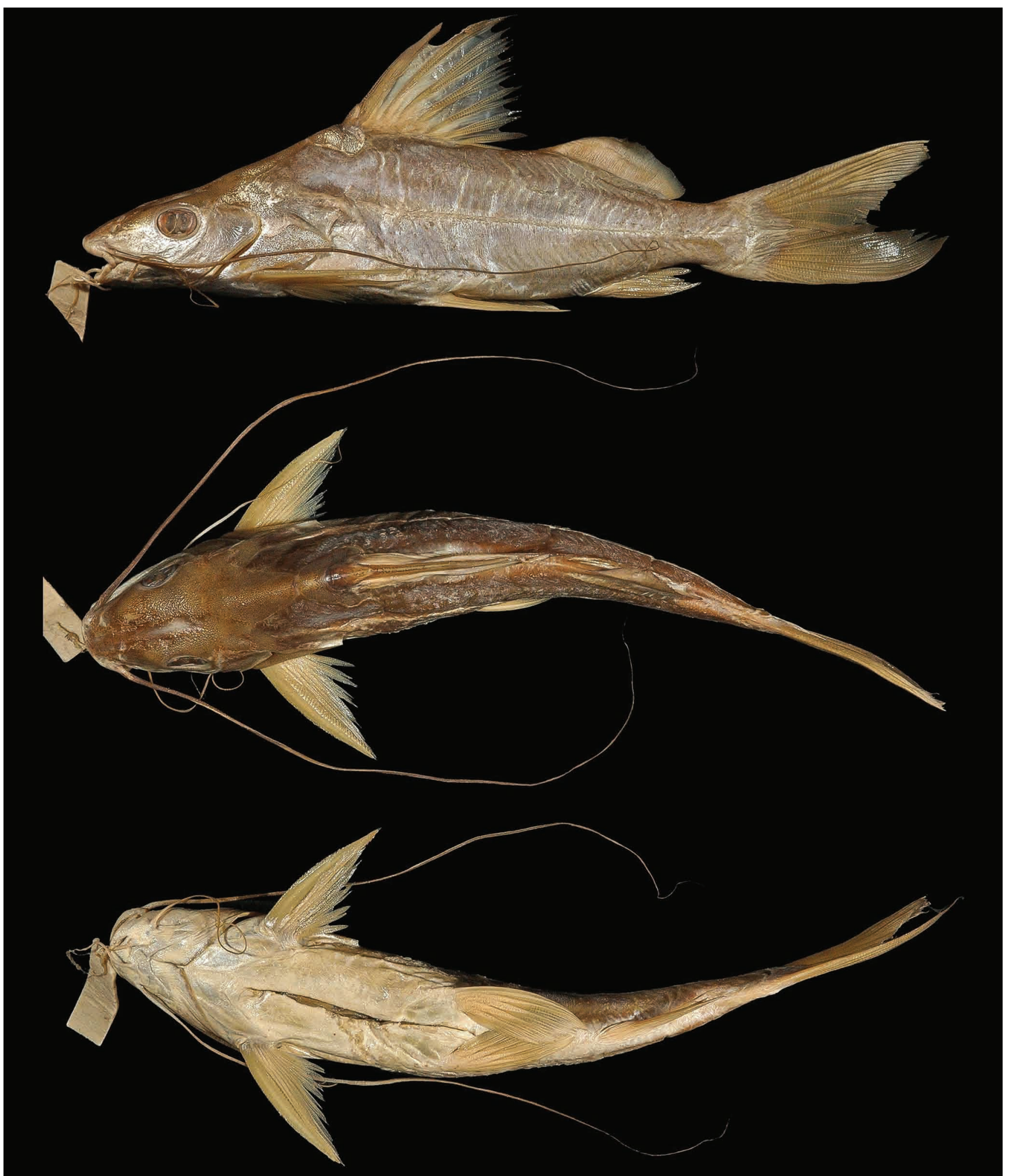

Fig. 6. Pimelodus argenteus, syntype, MSNG 14570, $165 \mathrm{~mm}$ SL, río de la Plata, río Paraná, Colonia Resistencia [Departamento San Fernando], Argentina. Photo by Mark Allen. 
The geographic distribution of Pimelodus argenteus includes the lower río Paraná and rio Paraguay basins, although it seems to be not common in the río de la Plata (M.S.R. pers. obs. and D. Nadalin pers. comm.) (Fig. 7).

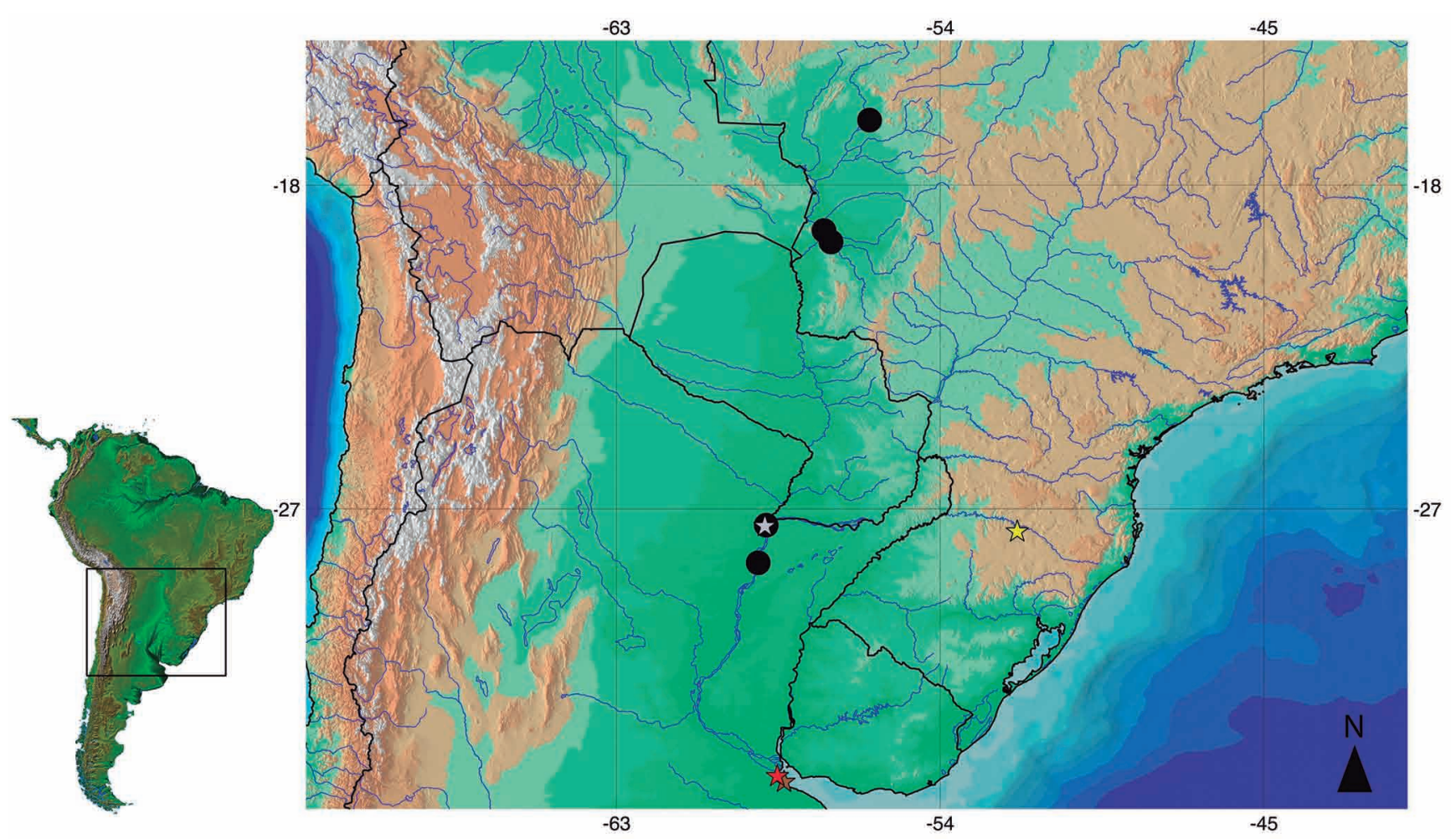

Fig. 7. Partial map of South America with the geographic distribution of Pimelodus argenteus (black dots) and the type localities of P. albicans (brown star); P. atrobrunneus (yellow star); P. argenteus (gray star), and P. brevis (red star).

\section{Discussion}

Some works have reported $P$. brevis as valid and even with a wide distribution (e.g., Ringuelet, 1940; Ringuelet et al., 1967; López et al., 2003). The first two provided both description and short diagnosis, translated from the original description, and no list of specimens analyzed. The last listed $P$. brevis as valid species and included the río Durazno, widening its geographical distribution range, but also without giving numbers of voucher specimens.

As evidenced by the holotypes of $P$. albicans and $P$. brevis [herein a junior synonym of $P$. argenteus], largesize pimelodids perhaps had been captured frequently in the last century, but nowadays large catfishes in the rio Paraná basin are uncommon, specially those species that knowingly reached large sizes in the past, such as Pseudoplatystoma Bleeker and Zungaro Bleeker species.

Stewart (1986), reviewing Pimelodina Steindachner, also concluded that $P$. Alavipinnis Steindachner, 1876 (holotype $288 \mathrm{~mm} \mathrm{SL}$ ), is the senior synonym of $P$. nasus Eigenmann \& Eigenmann, 1888 (holotype $333 \mathrm{~mm} \mathrm{SL}$ ). Stewart (1986) noted that differences between the two species given by Eigenmann \& Eigenmann (1890) were due to allometries caused by different sizes of the holotypes. The orbital diameter had negative allometry relative to standard length and then the holotype of $P$. nasus had relatively smaller orbital diameter than the holotype of P. flavipinnis. Therefore all diagnostic features related to the size of the eye, such as head length and interorbital space divided by orbital diameter could be explained by the negative allometry of the eye (Stewart, 1986).

A description based on a single large specimen probably has been the cause of such problematical taxonomic status, since $P$. argenteus and $P$. albicans are clearly different but, without known large specimens currently available, those variations consequence of difference in size were being used as diagnostic characters. Furthermore, the lack of the holotype had a major role in the status of the species for more than 50 years.

We conclude that $P$. brevis is a junior synonym of $P$. argenteus, even without examination of the holotype that is missing, by estimating allometries and considering variations in ontogenetic development of congeners. In cases of missing type-material, we recommend this practice, whenever possible, in order to elucidate similar taxonomic problems, common with species described in the late ninth and early twentieth centuries. Also to avoid such problems from happening even nowadays, we reiterate the recommendation that type-series includes several specimens, with different sizes and sexes, as well as depositing type-material in different institutions. 
Material examined. Pimelodus albicans: Argentina: ANSP 178802, 2 dry skeletons, unmeasured, Buenos Aires Province, río La Plata (Atlantic dr.) near La Plata, town of Ensenada fishing pier. ANSP 187383, 1, 144.4 mm SL, Corrientes, río Corrientes (tributary to the río Paraná) at Esquina. MLP 5871, 1, 98.1 mm SL, Buenos Aires, Ensenada, Punta Lara. MLP 6833, 1, 181.3 mm SL, Santa Fe, Rosario. MLP 8681, 3, 73.8-87.7 mm SL, Santiago del Estero, Desague en la rampa de la presa de río Hondo. MNHN 9400, 485 mm SL, Buenos Aires, holotype of Pimelodus albicans Valenciennes, 1840. MLP uncat, 2, 125.3$136.4 \mathrm{~mm}$ SL, río Corrientes. Pimelodus argenteus: Argentina: MCP 19248, 3 of 4, 143.4-204.7 mm SL, Corrientes, Bella Vista, río Paraná. MSNG 14570, 2, syntypes of Pimelodus argenteus, río de la Plata, río Paraná (Colonia Resistencia). Brazil: Mato Grosso State: NUP 613, 20, unmeasured, Barão de Melgaço, Lagoa da Fazenda Mimoso. Mato Grosso do Sul State: MZUEL 3403, 9, unmeasured, Corumbá, rio Paraguai, Porto da Manga, pesqueiro do Rubens. MZUEL 3404, 11, unmeasured, Bonito, rio Miranda. MZUEL 3498, 9, 137-178.9 mm SL, Corumbá, rio Paraguai, Porto da Manga, pesqueiro do Rubens. MZUEL 3609, 6, unmeasured, Corumbá, rio Miranda, Passo do Lontra. Paraná State: NUP 6334, 1, unmeasured, Diamante do Norte, Rosana Reservoir (rio Paranapanema). Pimelodus atrobrunneus: Brazil: Rio Grande do Sul State: MCP 18912, 1 c\&s, 104.9 mm SL, rio Uruguai in município de Marcelino Ramos. MCP 19678, 1, 129.8 mm SL, holotype of Pimelodus atrobrunneus Vidal \& Lucena, 1999, rio Ligeiro, rio Uruguai basin. UFRGS 10123, 1, $152.9 \mathrm{~mm}$ SL, rio Marmeleiro, rio Uruguai basin. UFRGS 11841, 1, 113.4 mm SL, Quevedos, rio Toropi, rio Ibicuí basin, Toropi - Guassupi Small Hydropower Plants. UFRGS 11842, 1, 129.1 mm SL, São Martinho da Serra, rio Toropi, rio Ibicuí área, Toropi - Guassupi Small Hydropower Plants. Santa Catarina State: MCP 20402, 1, $121 \mathrm{~mm}$ SL, rio Uruguai.

\section{Acknowledgments}

We are grateful to the following curators for assistance with visits and material's analyses: J. Lundberg, M. Sabaj Pérez and K. Luckenbill (ANSP), H. Lopes, A. Miquelarena and D. Nadalin (MLP), M. Azpelicueta (AI), O. Shibatta (MZUEL), R. Reis and C. Lucena (MCP), F. Carvalho and L. Malabarba (UFRGS). L. Rapp PyDaniel kindly provided support and assistance at INPA. A. Canto (UFOPA) provided the photo of P. argenteus. D. Stewart kindly provided all the measurements of the types of $P$. albicans and $P$. argenteus. Financial support to MSR was provided by a postdoctoral scholarship by the Conselho Nacional de Desenvolvimento Científico e Tecnológico (CNPq \# 150628/2013-7) under Edital MCT/ CNPq/MEC/CAPES/PROTAX n ${ }^{\circ}$ 52/2010 - Programa de Capacitação em Taxonomia. CSP is member of the US National Science Foundation project entitled "Planetary Biodiversity Inventory: All Catfish Species Inventory (ACSI)" and has grants from the Conselho Nacional de Desenvolvimento Científico e Tecnológico (CNPq \# 308946/2012-0).

\section{Literature Cited}

Eigenmann, C. H. \& R. S. Eigenmann. 1890. A revision of the South American Nematognathi or cat-fishes. Occasional Papers of the California Academy of Sciences, 1: 1-508.

Eschmeyer, W. N. (Ed.). Catalog of Fishes: Genera, Species, References. Electronic version 15 Jun 2014. Available from: http://research. calacademy.org/ichthyology/catalog/fishcatmain.asp (15 Jun 2014).

Ferraris Jr., C. J. 2007. Checklist of catfishes, recent and fossil (Osteichthyes: Siluriformes), and catalogue of siluriform primary types. Zootaxa, 1418: 1-628.

Graça, W. J. \& C. S. Pavanelli. 2007. Peixes da planície de inundação do alto rio Paraná e áreas adjacentes. Maringá, EDUEM.

López, H. L., A. M. Miquelarena \& R. C. Menni. 2003. Lista comentada de los peces continentales de la Argentina. ProBiotA - Serie Técnica y Didáctica, 5: 1-85.

Lundberg, J. G. \& M. W. Littmann. 2003. Pimelodidae. Pp. 432-446. In: Reis, R. E., S. O. Kullander \& C. J. Ferraris, Jr. (Eds.). Check list of the Freshwater Fishes of South and Central America. Porto Alegre, Edipucrs.

Lundberg, J. G. \& L. A. McDade. 1986. On the South American catfish Brachyrhamdia imitator Myers (Siluriformes, Pimelodidae), with phylogenetic evidence for a large intrafamilial lineage. Notulae Naturae (Philadelphia), 463: 1-24.

Lundberg, J. G. \& B. M. Parisi. 2002. Propimelodus, new genus, and a description of Pimelodus eigenmanni van der Stigchel, 1946, a long recognized yet poorly-known South American catfish (Pimelodidae: Siluriformes). Proceedings of the Academy of Natural Sciences, Philadelphia, 152: 75-88.

Marini, T. L. 1934. La piscicultura en nuestro país y en los EE. UU. Buenos Aires, Talleres gráficos Ferrari Hnos.

Marini, T. L., J. T. Nichols \& F. R. La Monte. 1933. Six new eastern South American fishes examined in the American Museum of Natural History. American Museum Novitates, 618: 1-7.

Pozzi, A. J. 1945. Sistemática y distribución de los peces de agua dulce de la República Argentina. GAEA, Argentina, 7: 239-292.

Ribeiro, F. R. V. \& C. A. S. Lucena. 2007. Pimelodus microstoma Steindachner, 1877, a valid species of pimelodid catfish (Siluriformes: Pimelodidae) from the upper rio Paraná drainage. Neotropical Ichthyology, 5: 75-78.

Ribeiro, F. R. V., C. A. S. Lucena \& O. T. Oyakawa. 2011. A new species of Pimelodus La Cépède, 1803 (Siluriformes: Pimelodidae) from rio Ribeira de Iguape basin, Brazil. Neotropical Ichthyology, 9: 127-134.

Ringuelet, R. A. 1940. La Estación Hidrobiológica de Rosario. Notas del Museo de La Plata (Zoologia), 5: 95-109.

Ringuelet, R. A. \& R. H. Aramburu. 1957. Enumeración sistemática de los vertebrados de la Provincia de Buenos Aires. Ministerio de Asuntos Agrarios de la Provincia de Buenos Aires, La Plata, Argentina, 19: 1-94.

Ringuelet, R. A., R. H. Aramburu \& A. A. Aramburu. 1967. Los peces argentinos de agua dulce. La Plata, Comisión de Investigación Científica de la Provincia de Buenos Aires.

Rocha, M. S. \& F. R. V. Ribeiro. 2010. A new species of Pimelodus LaCépède, 1803 (Siluriformes: Pimelodidae) from rio Itacaiunas, rio Tocantins basin, Brazil. Zootaxa, 2343: 57-65.

Stewart, D. J. 1986. Revision of Pimelodina and description of a new genus and species from the Peruvian Amazon (Pisces: Pimelodidae). Copeia, 1986: 653-672.

Submitted April 21, 2014

Accepted July 24, 2014 by Fernando R. Carvalho Published December 27, 2014 